\title{
Bibliometric analysis of global research on white rot fungi biotechnology for environmental application
}

\author{
Pengfei Xiao ${ }^{1}\left(\mathbb{D} \cdot\right.$ Dedong $\mathrm{Wu}^{1} \cdot$ Jianqiao Wang $^{2}$ \\ Received: 29 December 2020 / Accepted: 29 July 2021 / Published online: 5 August 2021 \\ (C) The Author(s), under exclusive licence to Springer-Verlag GmbH Germany, part of Springer Nature 2021
}

\begin{abstract}
In recent years, white rot fungi (WRFs) have received tremendous attention as a biotechnological tool for environmental pollution control. In order to systematically and comprehensively describe the progress, trends, and hotspots of WRF biotechnology in the field of environmental pollution control, the 3967 related publications from 2003 to 2020 were collected from Web of Science Core Collection database, and the bibliometric characteristics including publication output, country, institution, journal, author, citation frequency, h-index, and research focus were evaluated by using Excel 2007, CiteSpace V, and VOSviewer. The results indicated that the number of research publications increased rapidly before 2009, but after that, the number of publications fluctuated in a certain range. China and USA were the most productive countries and the most active country in international cooperation. In this field, most authors tend to cooperate within a small group. The journal and subject category with the largest number of publications are "International Biodeterioration \& Biodegradation" and "Biotechnology Applied Microbiology", respectively. The analysis of high-frequency keywords revealed that "laccase", "biodegradation", "decolorization", and "Phanerochaete chrysosporium" were the most cited terms among all publications. The pretreatment of biomass waste, decolorization of dye wastewater, and bioremediation of polluted environment are the key research directions of WRF biotechnology. Finally, the frontier topics and active authors in this research field were identified using burst detection. We believe that this bibliometric study provides a comprehensive and systematic overview and promoted the future cooperative research and knowledge exchange in this field of WRF biotechnology for environmental applications.
\end{abstract}

Keywords Bibliometric analysis · White rot fungi · Environmental applications · Web of Science Core Collection · Collaborative relationship $\cdot$ Visualization

\section{Introduction}

The rapid development of industrial activities has greatly increased the release of toxic and harmful substances into the environment, and the contamination of soil, water, and air by toxic and harmful chemicals has become one of the major environmental problems in the world today. These dangerous

\section{Responsible Editor: Philippe Garrigues}

Pengfei Xiao

xpfawd@nefu.edu.cn

1 College of Forestry, Northeast Forestry University, Hexing Road 26, Harbin 150040, China

2 Key Laboratory for Water Quality and Conservation of the Pearl River Delta, Ministry of Education, School of Environmental Science and Engineering, Guangzhou University, Guangzhou 510006, China compounds have carcinogenic and/or mutagenic effects, persistent in the environment and may have negative effects on human health and ecology (Almetwally et al. 2020). Due to the magnitude of this problem, there is an urgent need for a rapid, cost-effective, ecologically responsible method to remove pollutants. Most research in the field of bioremediation has focused on bacteria, and fungal remediation attracting much attention just in the past three decades (Singh et al. 2015). Mycoremediation is a promising technology using their metabolic potential to remove xenobiotics. White rot fungus (WRF) is an eco-physiological group mainly composed of basidiomycetes and litter-decomposing fungi. It is well known that WRF can degrade lignin in the way that the mycelium of organism penetrates the cell cavity and releases ligninolytic enzymes (LEM) to decompose the substance into white sponge-like mass (Cabana et al. 2007). These extracellular LEM have very low substrate specificity, so they are able to degrade a wide range of highly organopollutants that are 
structural similar to lignin. Their capacities to remove xenobiotic substances into less or non-toxic substances make them a useful and powerful tool for bioremediation of polluted environment (Lebkowska and Zaleska-Radziwill 2014; Xiao and Kondo 2019). In fact, WRFs are robust, ubiquitous organisms that can survive in the presence of high concentrations of various pollutants, even with a low bioavailability (Xiao and Kondo 2020a). In addition, WRFs have an advantage over bacteria in terms of the diversity of compounds that can be oxidize.

In recent years, researchers in different countries around the world have conducted many systematic reviews on development of WRF biotechnology for environmental applications. Asif et al. (2017a) reviewed the performance of WRF and its LEM to degrade trace organic pollutants from synthetic and real wastewater. In another review by the same author, the removal mechanism, degradation pathway, and the formation of intermediate byproducts in bioconversion of personal care products and pharmaceuticals using whole cell WRF and its LEM were discussed in detail (Asif et al. 2017b). A recent report from Mir-Tutusaus et al. (2018) reviewed the WRF-based technologies for micropollutant removal from wastewater, and proposed a series of solutions to overcome several limitations of this technology. Another review by Huang et al. (2018) introduced the trends in the application of WRF biocatalysis and its related combined technology such as adsorption of nanomaterials, for biotransformation of endocrine-disrupting compounds. He et al. (2017) proposed that in the process of wastewater treatment, nanoparticles as supports or synergist can improve the biodegradation performance and stability of WRF. Furthermore, Voberkova et al. (2018) summarize current progress in the use of immobilized LEM form WRF for treatment of wastewater, decolorization of dyes, or elimination of pharmaceutical active compound. Grelska and Noszczynska (2020) review WRF application for removal of endocrine-disrupting chemicals such as bisphenol A, bisphenol S, and nonylphenol from wastewater, and indicate several strengths and limitations of such methods. In a recent review, Zhuo and Fan (2021) comprehensively document the application of WRF and their lignocellulolytic enzymes for removing organic pollutants and highlighted potential problems and intriguing observations.

Although there have been a large number of research and review articles on the application of WRF biotechnology for environmental pollution control, it is difficult for traditional review articles to organize, summarize, and quantify the development of a certain field effectively on a large time scale. Bibliometric analysis is defined as a tool for the statistical and quantitative analysis of research publications that can quantify the literature growth of specific subjects and the impact of individual research results, and is a good choice for assessing trends in research activities. Bibliometric analysis can reveal the current research status and development trend through by evaluating the countries, institutions, authors, and keywords related to publications, and help scholars grasp the development characteristics of a certain research field, and better guide their future work (Li et al. 2017; Gao et al. 2019).

Bibliometric methods have been more and more widely applied in the field of environmental pollution control. For example, Singh and Borthakur (2018) conducted a review of the biodegradation and photocatalytic degradation of organic pollutants with bibliometric and comparative analysis. Li et al. (2019) discussed the research hotspots and trends in the field of phytoremediation in heavy metal pollution by using the bibliometric analysis. Based on bibliometric method, Qi et al. (2019) analyzed the research status and development trend of algae-bacteria symbiotic wastewater treatment technology between 1998 and 2017. Usman and Ho (2020) investigated the publications on the application of Fenton oxidation in soil remediation and wastewater treatment using bibliometric methods, and further pointed out the future development trend. In addition, a number of studies have carried out systematic bibliometric analysis on municipal solid waste (Chen et al. 2015), groundwater remediation (Zhang et al. 2017), and soil remediation (Vanzetto and Thomé 2019). However, to the best of our knowledge, few studies have attempted to comprehensively review the development of WRF biotechnology on environmental pollution control based on bibliometric methods over time and by region.

Through bibliometric analysis, the core technology and research direction of WRF biotechnology in environmental application can be revealed, which is beneficial to strengthening knowledge accumulation and the capabilities of theoretical innovation, thereby promoting the further utilization of WRF biological resources in global research. Considering these reasons, a comprehensive and systematic perspective on the environmental application research of WRF biotechnology was motivated to provide in this study, based on the bibliometric method. The purpose of this study is to (1) identify the most productive and influential countries, institutions, journals, and authors; (2) analyze the cooperation relationships at the level of countries, institutions, and authors; (3) understand the knowledge domains and research topics with keyword analysis; and (4) propose research frontiers in the future within this research field.

\section{Materials and methods}

\section{Data sources}

Scientific output data was extracted from the Web of Science Core Collection (WoSCC), which is one of the most widely used databases in academic and bibliometric studies and allows the download of full citation records with new records 
being updated every day (AlRyalat et al. 2019). WoSCC can provide comprehensive information for bibliometric analysis, including the Science Citation Index-Expanded (SCI-E) and the Social Sciences Citation Index (SSCI). This database was used to retrieve the related research of WRF biotechnology in environmental application for the period from 2003 to 2020 . To find different variations among the words in the databases, a wildcard $(*)$ was used. Data retrieval strategy of this study is as follows: TS = (“"white rot fungi" or "white rot fungus" or "white rot fungal" or "white rot basidiomycete") and ("*degrad*" or "treatment" or "remov*" or "*remediation" or "*conversion" or "*transformation" or "decolorization" or "elimination" or "detoxification")). The language is limited to English. As a result, a total of 3967 publications were obtained for further analysis. These data, which includes full records, were downloaded and exported in text format for further analysis. All data was exported within on June 13, 2021, to avoid deviations caused by the daily updates of this database.

\section{Analysis methods}

The publication characteristics (publishing year, counties, institutions, authors, and subject categories) were analyzed using Microsoft Office Excel 2007. Some conventional methods in bibliometrics, including citation analysis, social network analysis, co-word clustering analysis, and burst detection, are employed in this study. The total citations, average citations per article, and h-index obtained from citation reports of WoSCC were used for citation analysis. The impact factor (IF) of journals was collected form the Journal Citation Report in 2019. VOSviewer software has text mining capabilities to extract important terms from a large number of scientific literatures for construction and visualization of co-occurrence networks (van Eck and Waltman 2010). In this study, VOSviewer 1.6.15 was used to generate social network maps for cooperative relationship analysis and co-occurring keywords analysis in related research fields. In addition, the software is also used to extract the high frequency keywords published in this field in different countries and time periods. The network maps are composed of nodes and links, where nodes represent elements such as counties, institutions, authors, and keywords. The nodes represent the number or frequency, and the lines between the nodes denote associations. The thicker the line is, the greater the relationship. In the parameter settings of VOSviewer, the counting method adopts full counting, and the maximum number of authors per document is set to 25. Furthermore, Citespace V is a free software package for scientific visualization based on Java, which is utilized to identify research trends and active authors through burst detection (Yang et al. 2018). For instance, in the burst analysis with keywords, the appearance of a keyword burst in a period of time, which means that a related field represented by this burst keyword has attracted extensive attention of researchers, and may become a research hotspot in the future. It should be pointed out that some repetitive and unrelated words are excluded from the results of keyword analysis and burst detection.

\section{Results and discussion}

\section{Document types}

A total of 3967 records related to WRF biotechnology for environmental application was identified which are classified into eight document types indexed in the WoS (Table 1). Article was the most frequently used document type, accounting for $90.98 \%$ of the total publications, followed distantly by review $(8.32 \%)$. Others include proceedings paper $(2.85 \%)$, meeting abstracts $(0.53 \%)$, early access $(0.38 \%)$, editorial materials $(0.72 \%)$, book chapter $(0.25 \%)$, correction $(0.13 \%)$, and editorial material $(0.05 \%)$, which showed lower significance than article and review. It is thus obvious that the article and review with the largest proportion may greatly reflect the development trends and change in this research field. It should be pointed out that some research reports on original works were classified as article and review at the same time, which will cause the sum of percentages in all types is greater than $100 \%$.

\section{Publication outputs}

Figure 1 shows the yearly numbers of related publications from 2003 to 2020. Specifically, the number of publications on WRF biotechnology for environmental application increased significantly from 134 in 2003 to 251 in 2009, and the number of publications has almost doubled, which indicating the growing interest in scientific community to this research field. This is mainly due to the great attention paid by China, India, and Spain in this period. However, it is interesting to note that after 2009 , the number of publications

Table 1 Document types of publications on WRF biotechnology for environmental application from 2003 to 2020

\begin{tabular}{llll}
\hline Rank & Types & Numbers & Percentage (\%) \\
\hline 1 & Article & 3609 & 90.98 \\
2 & Review & 330 & 8.32 \\
3 & Proceedings paper & 113 & 2.85 \\
4 & Meeting abstract & 21 & 0.53 \\
5 & Early access & 15 & 0.38 \\
6 & Book chapter & 10 & 0.25 \\
7 & Correction & 5 & 0.13 \\
8 & Editorial material & 2 & 0.05 \\
\hline
\end{tabular}


Fig. 1 The number of publication in the field of WRF

biotechnology for environmental application in the world and main productive countries from 2003 to 2020

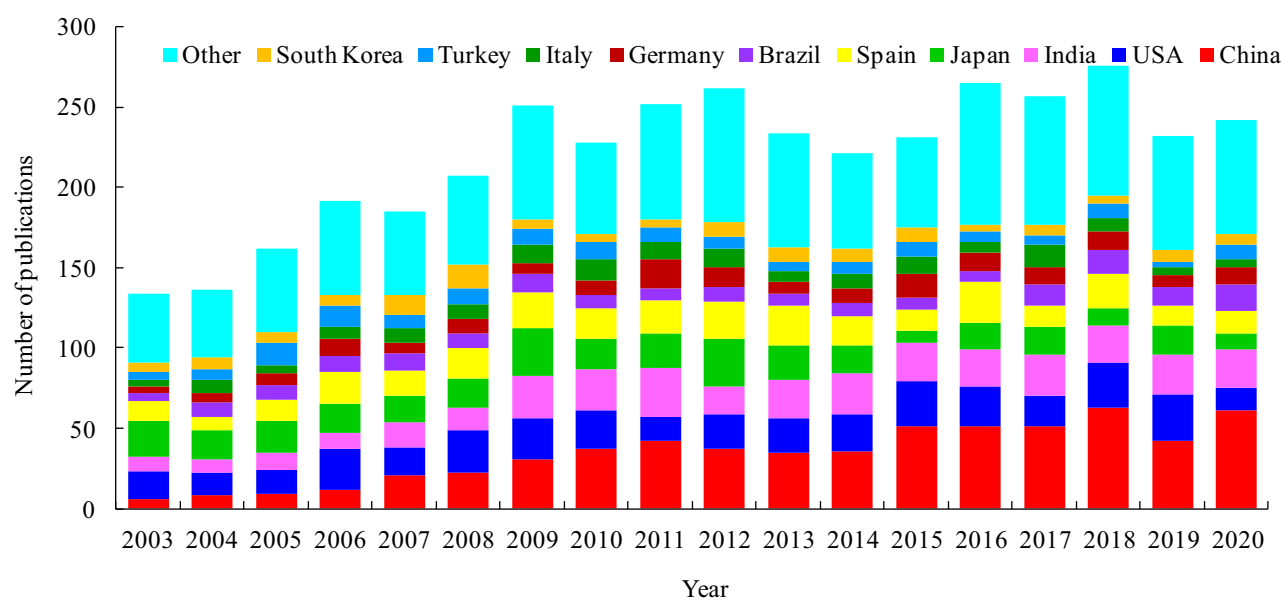

around the world shows a regular fluctuation. In particular, in 2014 , the number of publications dropped to 221 at the bottom, and then increased gradually, reaching the highest of 276 in 2018, and then falling to 232 again in 2019. It can be seen that since 2009, the number of publications has not shown a straight line growing trend, and has always fluctuated within a certain number range. It is expected that the research will enter a stable period in the future. In 2020 , only 242 publications have been published in this field worldwide, which may be related to the impact of COVID-19 on research.

\section{Countries and collaborations}

In 2003, only 41 countries/regions published articles in this field, while 94 countries/regions carried out related research by 2020 , indicating that there have been an increasing number of countries/regions participating in this research each year. Among these countries, 15 countries have published more than 100 publications. As shown in Table S1, China is the country producing maximum research outputs on this period with 613 publications, followed by the USA, India, Japan, and Spain, with more than 300 publications. The high output of publications in these countries can be explained by their strong economic strength and the huge investment in research, development, and innovation. It has to be noted that both developed countries (such as USA, Japan, Germany, and Italy) and developing countries (such as China, Brazil, India, and Turkey) were found to be developing research in environmental pollution control using WRF. However, in terms of the number of publications in this research field, there a relative heterogeneity among these countries. For example, the number of publications by the first ranked China is more than 200 than that of the second ranked USA, while Brazil and Germany as the 6th and 7th ranked countries have published 176 and 170 publications respectively, accounting for only a third of China's publications on the topic. The USA, Italy, and Spain were significantly ahead of other countries in terms of publication output in the early years, but after 2007, China gradually narrowed the gap with leading countries and became the leader (Fig. 1). On the other hand, in terms of total citations, citations per article, and h-index, the USA surpassed China and ranked first. Although China has the largest number of publications, the average citation frequency of publications is only 23.28 , less than half of that of the USA (48.05); more efforts still should be engaged for improving academic influence.

Academic cooperation between different countries or research institutions plays a guiding role in promoting dissemination of knowledge and academic exchange among scholars (Chen et al. 2020). The academic cooperation relationship among the top 30 countries of publications from 2003 to 2020 was shown in Fig. 2a. The nodes in the figure represent different countries, the lines connecting the nodes indicate international cooperation between countries, and thickness of the line represents the closeness of cooperation. It can be seen that the USA is the most active country in global cooperation on research of WRF biotechnology for environmental application, and is located at the center of the collaborative network. USA has cooperated with 52 countries to produce publications in relevant research, followed by Germany (42), Sweden (41), Spain (40), France (40), British (33), Japan (32), and China (31). In terms of the number of cooperative publications, the USA and China had the closest collaboration, followed by USA-Canada, Brazil-Chile, USA-Spain, and USA-Germany. As the country with the largest number of publications, China has not cooperated closely with other countries except the USA, thus should greatly strengthen its academic cooperation with other countries. Additionally, there is still much room for the development in cooperation and exchange in this research field between countries. For example, the USA and China, the two major countries with the largest publications, have never collaborated with Russia and Argentina. 
(a)

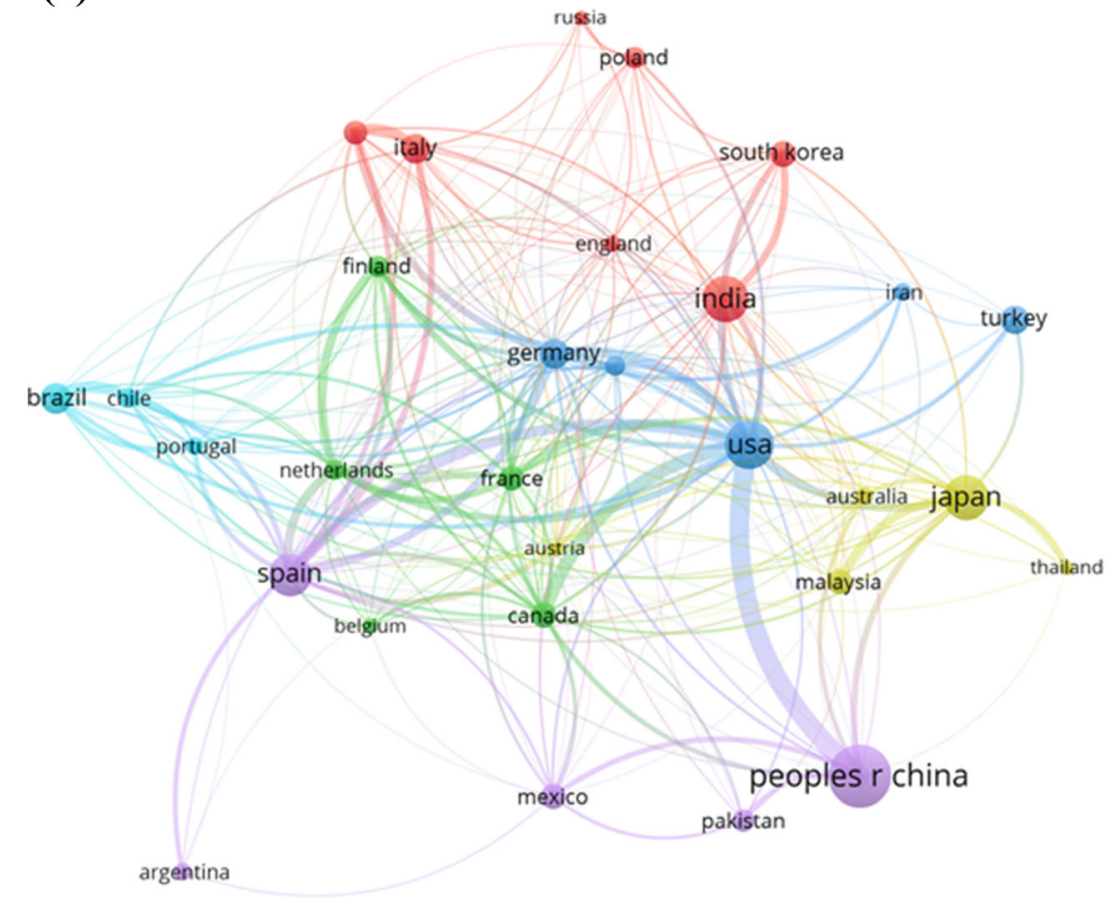

(b)
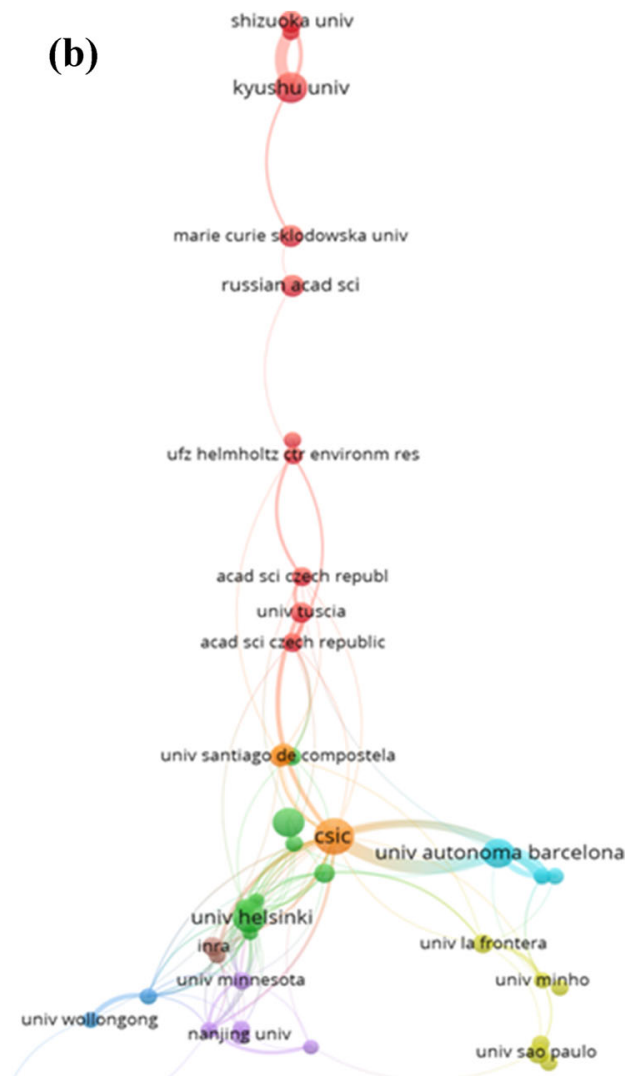

huazhong univ sci \& technol

Fig. 2 The academic collaboration networks among the top 30 productive countries (a) and the top 40 productive institutions (b)

\section{Institutions and collaborations}

More than 2400 institutions have contributed publications on the field of WRF biotechnology for environmental application. Table $\mathrm{S} 2$ showed top 10 productive institutions and their relevant indicators. The top 10 institutions completed 817 publications totally, accounting for $20.59 \%$ of total publications. The top 10 institutions belong to eight countries, with Spain, China, and Japan each having two, and Czech Republic, Finland, Pakistan, and the USA each having one. It is worth noting that there are no institutions from India, Brazil, or Germany in the top 10 most productive institutions. The Consejo Superior de Investigaciones Cientificas (CSIC) from Spain has the most publications (154), followed by Czech Academy of Sciences (100) and Chinese Academy of Sciences (CAS, 83). The CSIC also has the highest total citation (7231) and h-index (45), followed by Czech Academy of Sciences. A bias could appear here because these research institutions have branches in different cities, and publications classified according to their branches may lead to differences in rankings. In addition, although the US Department of Agriculture ranked only tenth in terms of the number of publications, their average citation frequency was the first with 77.84 , indicating that the high average quality of their publications. Of note, one author can belong to more than one institution and this fact can be a bias risk for institution analysis.

Figure $2 \mathrm{~b}$ showed the academic collaborations among institutions in the field of WRF biotechnology for environmental application. In terms of the number of cooperation institutions, CSIC cooperates with 112 institutions in this research field, and indicating that it has the closest cooperation relationship with other institutions. The top 10 cooperative organizations with the largest number of publications were CSIC - University of Autonama de Barcelona, University of Autonama de Barcelona-Universitat de Girona, Kyushu University-Miyazaki University, University of HelsinkiUtrecht University, Seoul National University-Korea Forest Research Institute, University of WollongongRMIT University, Hunan University-Hunan Agricultural University, CSIC - Universitat de Girona, Institut National de la Recherche Agronomique (INRA)-Aix Marseille University, and Charles University-Czech Academy of Sciences. Obviously, cooperation between different institutions often occurs in the same country, such as Spain, Japan, Korea, Australia, China, France, and Czech Republic, only the University of Helsinki-Utrecht University comes from different countries among the top 10 cooperative institutions. 
The results show that the CAS has cooperated with 46 other institutions, but most of them are domestic institutions. In recent years, the publications number from CAS in cooperation with institutions from Italy, UK, USA, Netherlands, Denmark, and Canada has continued to increase, indicating that CAS has made efforts to promote international cooperation. Cooperation between institutions from different countries is conducive to the development and dissemination of knowledge, thus international cooperation in this research fields needs to be closer.

\section{Authors and collaborations}

In general, more than 10000 authors participated in the researches of WRF biotechnology for environmental application from 2003 to 2020 . Figure 3 showed the top 20 productive authors in the number of publications and total citations. Of the top 20 authors, 6 authors were from Spain, 5 from Japan, 4 form China, 2 from Pakistan, and 1 from Malaysia, Czech Republic, and Costa Rica, respectively. Surprisingly, no authors from the USA and India, which ranked second or third in the number of publications published, entered the top 20 author list. Zhang Xiaoyu, from Huazhong University of Science and Technology, is the most productive author with 53 publications, followed by Asgher Muhammad from University of Agriculture Faisalabad (48). The number of publications by the third to eighth authors was between 31 and 39. With regards to total citation of publications, two Spanish authors, Vicent Teresa (1664) and Caminal Gloria (1565), can be regarded as the most concerned scholars for this research. In contrast, the total citations of several scholars from Japan are relatively low, among the top 20 authors. Another Spanish scholar, Marco-Urrea Ernest, ranked first among the top 20 authors with an average citation of 57.58.
By tracking the top authors, it is useful for other scholars to find classic and excellent publications in this research field. These results indicate that the publications of Spanish scholars in this field have the highest academic influence, and their work could have a deep impact on the future research of other scholars.

Figure 4 displayed the collaboration network of 69 most productive authors. This cooperation network includes a large cooperation network and several small cooperation networks which are not connected with each other. The large cooperative network has a cluster of many core authors, such as Caminal Gloria, Vicent Teresa, Martinez Angel T., Marco-Urrea E. from Spain, Rodriguez-Rodriguez Carlos E. from Costa Rica, and Cajthaml Tomas from Czech Republic, which can be regarded as the active and representative research team, providing highly personalized scientific reference for other related scholars. However, most authors tend to cooperate within a small group, such as those from Japan, China, and Pakistan, which leads to the lack of efficient cooperation among various groups. Co-publishing among authors, especially those from different industries or countries, needs to be valued, which can greatly promote the exchanges and innovation of academic ideas.

\section{Journals and subject categories}

Journals have a prominent role as the main disseminators of knowledge. A total of 628 journals published relevant researches from 2003 to 2020. Among these journals, 42.7\% (268) have published only one publication on WRF research for environmental application. Another $16.88 \%$ (106) of the journals have published two publications, 9.1\% (57) have published three, $4.3 \%$ (27) four, and $27.1 \%$ of the journals (170) have published five or more publications. The top 10

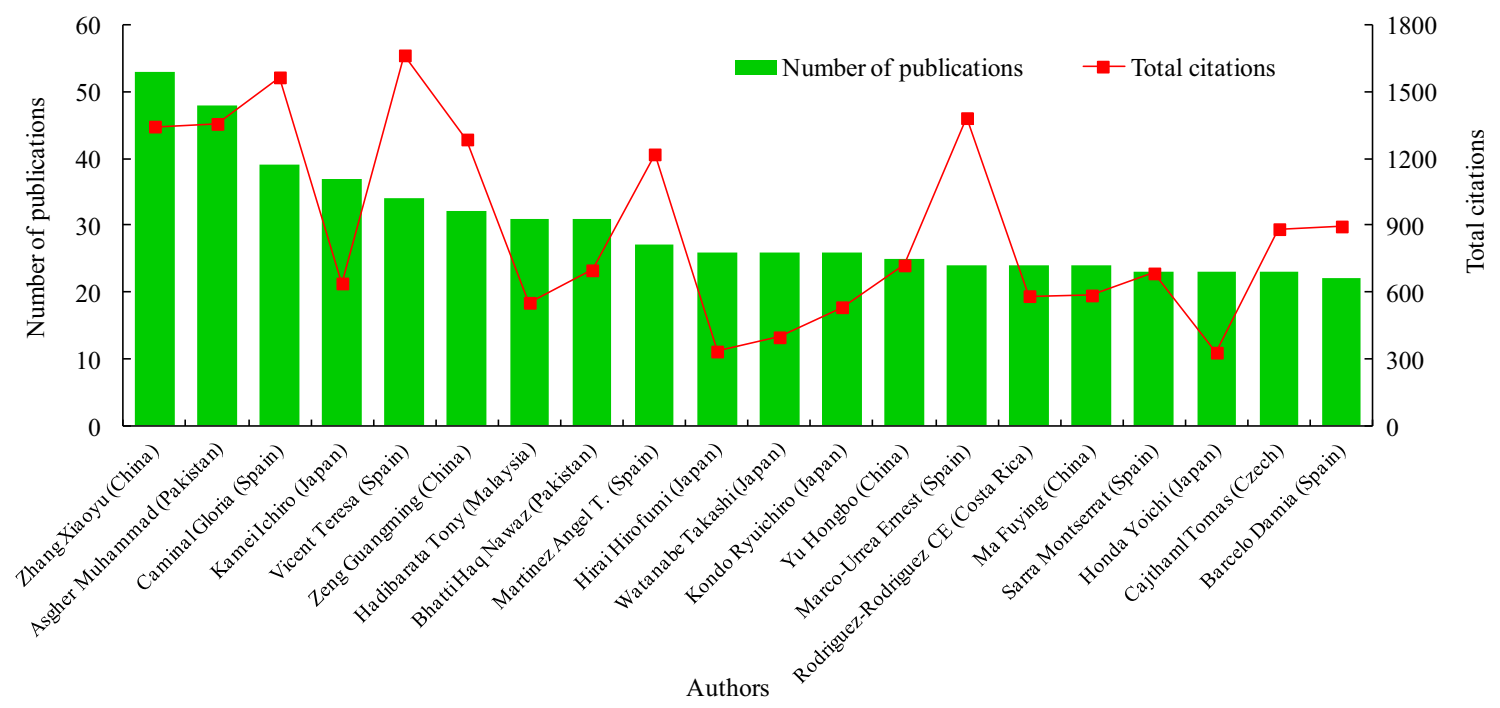

Fig. 3 The top 20 productive authors according to the number of articles and total citations 


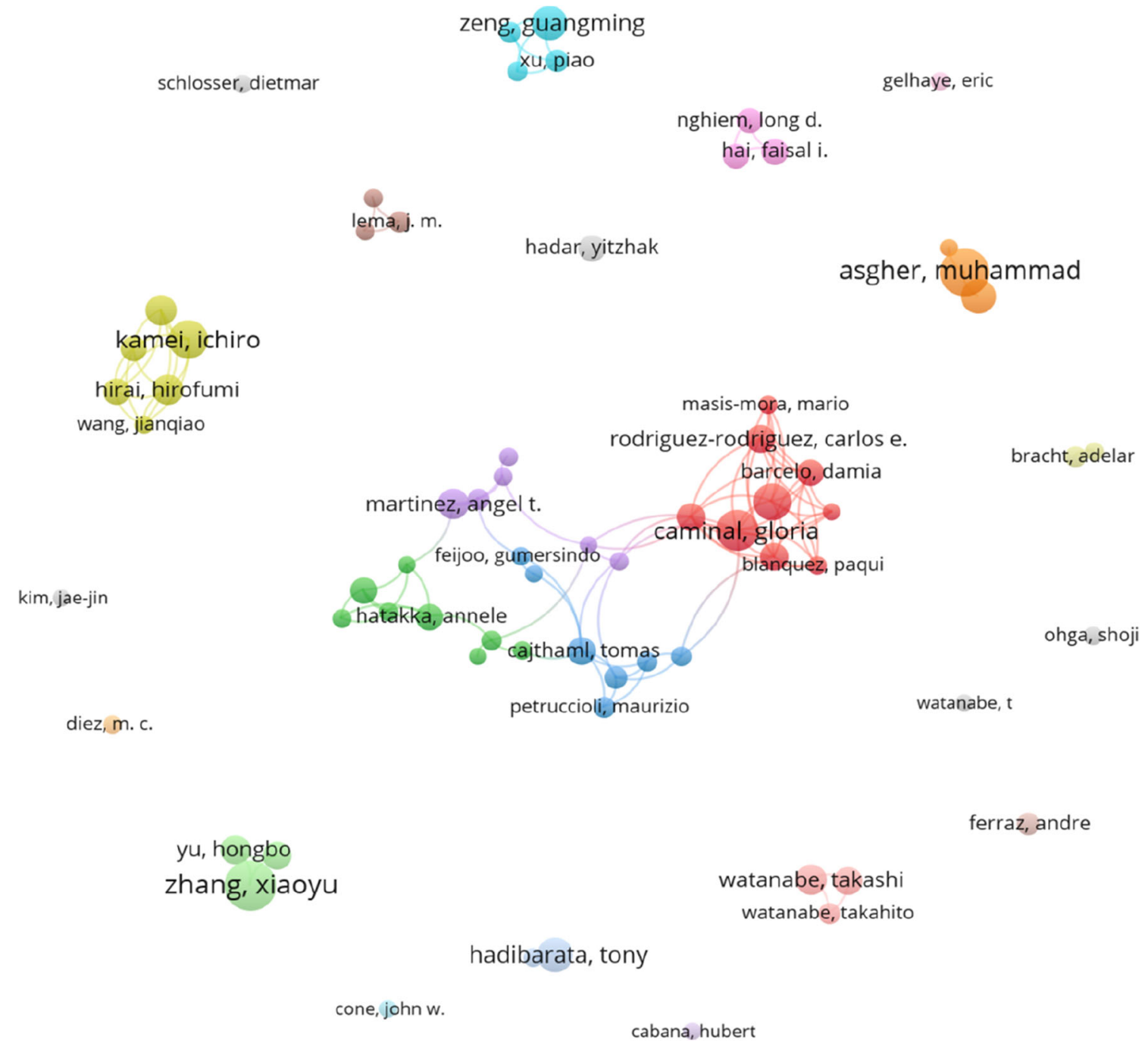

Fig. 4 The academic collaboration network among the top 69 productive authors

journals with the most productive published a total of 1060 publications in the research fields (Table S3). Except for "Chemosphere" and "Journal of Hazardous Materials", the other eight journals are the journals that mainly publish biological research articles. The most productive journal was "International Biodeterioration \& Biodegradation" with 195 publications covering $4.92 \%$ of the total publications, indicating that the research on the biodegradation ability of WRF and their enzymes has attracted much attention. The followed major journals were "Bioresource Technology" (182, 4.59\%), "Applied Microbiology and Biotechnology" (114, 2.88\%), and "Chemosphere" $(111,2.80 \%)$. The impact factors of these 10 journals ranged from 1.409 to 9.038 , and "Journal of Hazardous Materials" had the highest impact factor. "Bioresource Technology" not only received the highest number of total citations $(12,285)$ and average citations per publication (67.50), but also has the highest h-index (57).

All publications were divided into $90 \mathrm{Web}$ of Science subject categories, and Fig. 5a shows the top 10 most productive categories. It should be mentioned that the sum of percentages in all categories is greater than $100 \%$, because the same publications can be classified into multiple categories in WoS. Obviously, the category of "Biotechnology Applied Microbiology" contributed the largest number of 1616 publications (40.7\%), followed by "Environmental Sciences" (999, $25.2 \%$ ). However, there are no more than 500 publications in other categories such as "Microbiology" (434), "Biochemistry Molecular Biology" (353), and "Engineering Chemical" (316). Monitoring the temporal evolution of major categories (Fig. 5b), it can be observed that that the number of publications in the category of "Biotechnology Applied Microbiology" shows a fluctuating trend in 2003-2020, peaked at 127 in 2011, and then decreased gradually. The number of publications in category of "Environmental Sciences" increased significantly after 2008 and decreased slowly after experiencing two peaks in 2010 (73) and 2017 (82). Interestingly, the number of publications in category of "Environmental Sciences" exceeded the number of 
Fig. 5 The total output (a) and temporal evolution (b) of publications in different subject categories in the researches on WRF biotechnology for environmental application

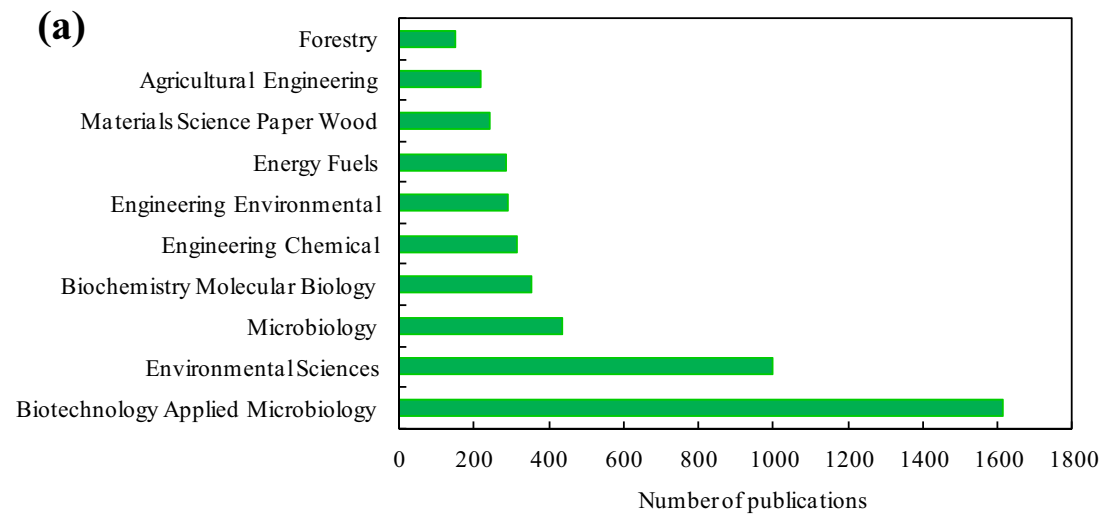

(b)

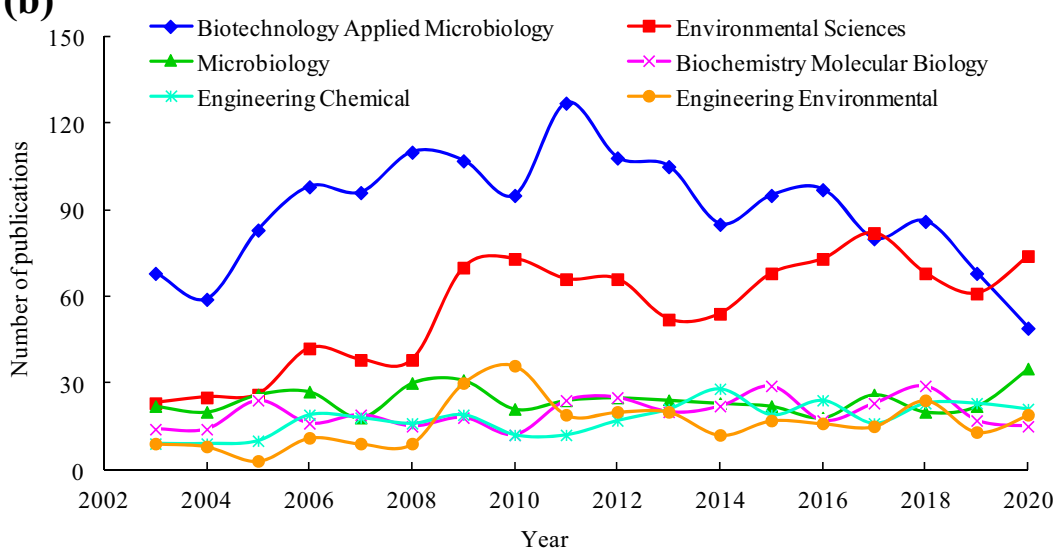

publications in category of "Biotechnology Applied Microbiology" in 2020, and the ranking rises to the first place. From 2003 to 2020, there is no significant fluctuation in the number of publications in other categories.

\section{Most cited articles}

Citation analysis has been regarded as an important indicator to measure the quality of publications in bibliometric research, and it represents the influence and attention of a research in the academic circles (He et al. 2019). Table 2 lists the 10 most frequently cited publications from 2003 to 2020 in the research field of WRF biotechnology for environmental application with relevant information including title, authors, journal, the country, total citations, and publication years. Eight research articles and two review articles entered the list of top 10 cited publications. Among the first authors of the top 10 cited publications, three are from the USA, and the other seven are from different countries. Surprisingly, in the top 10 citation list, there are no publications from the top 10 most productive countries except the USA, which shows that there is no close relationship between the highly cited publications and most productive countries.

The most highly cited publications is titled "Non-conventional low-cost adsorbents for dye removal: A review", authored by Crini (2006), in Bioresource Technology in
2006, with total 2804 times. The author introduces the application and feasibility of various low-cost adsorbents to remove dyes from wastewater, among which biosorption is a promising method to alternative traditional adsorption for dye removal. As a kind of biosorbent, the decolorization and/or biosorption ability of WRF to dye wastewater has become a research topic. In WRF decolorization, living biomass was often used to adsorb and degrade dyes, while dead biomass was applied to adsorb dyes. The publication with the second-highest number of citations (2023) is titled "Removal of synthetic dyes from wastewaters: a review", as authored by Forgace et al. (2004) and published in the Environmental International. This review described the various removal methods of synthetic dyes in wastewater by adsorption, oxidation, photodegradation, and microbiological decoloration. Using WRF to degrade synthetic dyes is a convenient, environmentally friendly and attractive method. Some strains, such as Phanerochaete chrysosporium (Kiran et al. 2019), Phlebia brevispora (Harry-Asobara and Kamei 2019), Irpex lacteus (Malachova et al. 2013), Trametes versicolor (Legerska et al. 2018), Pleurotus ostreatus (Dogan et al. 2018), and Pleurotus sajor caju (Yehia and Rodriguez-Couto 2017) have been demonstrated to be able to degrade synthetic dyes due to their high enzyme production. The remaining eight most frequently cited articles primarily focus on pretreatment and bioconversion of lignocellulosic wastes by WRF, treatment of industrial dye effluents by WRF 
Table 2 Top 10 most frequently cited publications from 2003 to 2020

\begin{tabular}{|c|c|c|c|c|c|c|c|}
\hline Rank & Title & $\begin{array}{l}\text { Paper } \\
\text { type }\end{array}$ & First author & Country & Journal & $\begin{array}{l}\text { Total } \\
\text { citations }\end{array}$ & Year \\
\hline 1 & $\begin{array}{l}\text { Non-conventional } \\
\text { low-cost adsor- } \\
\text { bents for dye re- } \\
\text { moval: A review }\end{array}$ & Review & Crini G & France & $\begin{array}{l}\text { Bioresource } \\
\text { Technology }\end{array}$ & 2927 & 2006 \\
\hline 2 & $\begin{array}{l}\text { Removal of } \\
\text { synthetic dyes } \\
\text { from wastewaters: } \\
\text { a review }\end{array}$ & Review & Forgace E & Hungary & $\begin{array}{c}\text { Environmental } \\
\text { International }\end{array}$ & 2119 & 2004 \\
\hline 3 & $\begin{array}{l}\text { Methods for } \\
\text { pretreatment of } \\
\text { lignocellulosic } \\
\text { biomass for } \\
\text { efficient } \\
\text { hydrolysis and } \\
\text { biofuel } \\
\text { production }\end{array}$ & Review & Kumar P & USA & $\begin{array}{l}\text { Industrial \& } \\
\text { Engineering } \\
\text { Chemistry } \\
\text { Research }\end{array}$ & 2101 & 2009 \\
\hline 4 & $\begin{array}{l}\text { Pretreatment of } \\
\text { lignocellulosic } \\
\text { wastes to improve } \\
\text { ethanol and } \\
\text { biogas } \\
\text { production: A } \\
\text { review }\end{array}$ & Review & $\begin{array}{l}\text { Taherzadeh } \\
\text { M J }\end{array}$ & Sweden & $\begin{array}{c}\text { International } \\
\text { Journal of } \\
\text { Molecular } \\
\text { Sciences }\end{array}$ & 1424 & 2008 \\
\hline 5 & $\begin{array}{l}\text { Fungal laccases - } \\
\text { occurrence and } \\
\text { properties }\end{array}$ & Review & Baldrian P & Czech & $\begin{array}{l}\text { FEMS } \\
\text { Microbiolo- } \\
\text { gy Reviews }\end{array}$ & 1363 & 2006 \\
\hline 6 & $\begin{array}{l}\text { The paleozoic origin } \\
\text { of enzymatic } \\
\text { lignin } \\
\text { decomposition } \\
\text { reconstructed } \\
\text { from } 31 \text { fungal } \\
\text { genomes }\end{array}$ & Article & Floudas D & USA & Science & 896 & 2012 \\
\hline 7 & $\begin{array}{l}\text { Lignocellulosic } \\
\text { residues: } \\
\text { Biodegradation } \\
\text { and bioconversion } \\
\text { by fungi }\end{array}$ & Review & Sanchez C & Mexico & $\begin{array}{l}\text { Biotechnology } \\
\text { Advances }\end{array}$ & 765 & 2009 \\
\hline 8 & $\begin{array}{l}\text { White-rot fungi and } \\
\text { their enzymes for } \\
\text { the treatment of } \\
\text { industrial dye } \\
\text { effluents }\end{array}$ & Review & $\begin{array}{l}\text { Wesenberg } \\
\text { D }\end{array}$ & Belgium & $\begin{array}{c}\text { Biotechnology } \\
\text { Advances }\end{array}$ & 738 & 2003 \\
\hline 9 & $\begin{array}{l}\text { Principles of } \\
\text { microbial } \\
\text { PAH-degradation } \\
\text { in soil }\end{array}$ & Review & $\begin{array}{l}\text { Johnsen A } \\
\text { R }\end{array}$ & Switzerland & $\begin{array}{l}\text { Environmental } \\
\text { Pollution }\end{array}$ & 730 & 2005 \\
\hline 10 & $\begin{array}{l}\text { Genome sequence } \\
\text { of the } \\
\text { lignocellulose } \\
\text { degrading } \\
\text { fungus } \\
\text { Phanerochaete } \\
\text { chrysosporium } \\
\text { strain RP78 }\end{array}$ & Article & Martinez D & USA & $\begin{array}{l}\text { Nature } \\
\text { Biotechnol- } \\
\text { ogy }\end{array}$ & 593 & 2004 \\
\hline
\end{tabular}


and their enzymes, occurrence and properties of laccases, fungal degradation of PAH in soil, and genome sequence analysis of WRF.

\section{High frequency keywords analysis}

Keywords clearly reflect the core content of the article in a concise form, which can be regarded as the soul of the article. By analyzing the high frequency keywords, the research hotspots and overall development trends in the field are accurately revealed (Qi et al. 2019). Using VOSviewer software to analyze the frequency of the author keywords, and then a total of 6605 keywords were collected, among which 4831 (73.1\%) keywords were used only once, 790 keywords (12.0\%) were used twice, and 224 keywords (4.6\%) appeared more than 10 times. The use of a large number of low frequency keywords indicated a wide range of research content and difference research focuses is field. The 20 most frequently used keywords during the period of 2003-2020 are shown in Table 3. Similar keywords with different writings, such as "white rot fungi", "white rot fungus", "white-rot fungi", and "white-rot fungus"; "decolourisation" and "decolourization"; and, "polycyclic aromatic hydrocarbons", "PAHs", and "PAH" were merged. The "white rot fungi", "laccase", "biodegradation", "decolorization", and "Phanerchaete chrysosporium" are the most frequently used five keywords, which shows that these keywords are favored by scholars all over the world. Except for "white rot fungi", "biodegradation", "bioremediation", "fungi", and "degradation" (the searching words in the present research), most of these keywords are mainly related to the following topics: WRF strains (Phanerchaete chrysosporium, Trametes versicolor, and Pleurotus ostreatus), degrading enzyme (laccase, manganese peroxidase, ligninolytic enzymes, and lignin peroxidase), treatment of dyes (decolorization and dye decolorization), degradation substrate (PAHs, lignin, and lignin peroxidase), and treatment and disposal methods (biosorption and immobilization).

By observing the changes of the ranking of most frequently used keywords in different periodsthe changes of hotspots in related research can be directly understood. The evolution of top 20 author keywords and frequency in different periods was also listed in Table 3 . The growth rates of author

Table 3 Top 20 author keywords and their frequency in different periods

\begin{tabular}{|c|c|c|c|c|c|c|c|c|}
\hline \multirow[t]{2}{*}{ Rank } & \multicolumn{2}{|l|}{ 2003-2020 } & \multicolumn{2}{|l|}{ 2003-2008 } & \multicolumn{2}{|l|}{ 2009-2014 } & \multicolumn{2}{|l|}{$2015-2020$} \\
\hline & Keywords & Frequency & Keywords & Frequency & Keywords & Frequency & Keywords & Frequency \\
\hline 1 & White rot fungi & 822 & White rot fungi & 234 & White rot fungi & 313 & White rot fungi & 275 \\
\hline 2 & Laccase & 606 & Laccase & 181 & Laccase & 235 & Laccase & 190 \\
\hline 3 & Biodegradation & 362 & Decolorization & 132 & Biodegradation & 158 & Biodegradation & 116 \\
\hline 4 & Decolorization & 210 & Biodegradation & 88 & Decolorization & 108 & Lignin & 77 \\
\hline 5 & $\begin{array}{l}\text { Phanerochaete } \\
\text { chrysosporium }\end{array}$ & 210 & $\begin{array}{l}\text { Manganese } \\
\text { peroxidase }\end{array}$ & 74 & $\begin{array}{l}\text { Phanerochaete } \\
\text { chrysosporium }\end{array}$ & 76 & Decolorization & 70 \\
\hline 6 & Bioremediation & 200 & $\begin{array}{l}\text { Phanerochaete } \\
\text { chrysosporium }\end{array}$ & 73 & Bioremediation & 73 & Ligninolytic enzymes & 70 \\
\hline 7 & $\begin{array}{l}\text { Manganese } \\
\text { peroxidase }\end{array}$ & 196 & Trametes versicolor & 63 & Ligninolytic enzymes & 68 & Fungi & 67 \\
\hline 8 & Trametes versicolor & 170 & Bioremediation & 60 & Trametes versicolor & 67 & Bioremediation & 67 \\
\hline 9 & Lignin & 168 & Lignin & 42 & $\begin{array}{l}\text { Manganese } \\
\text { peroxidase }\end{array}$ & 67 & $\begin{array}{l}\text { Phanerochaete } \\
\text { chrysosporium }\end{array}$ & 61 \\
\hline 10 & Ligninolytic enzymes & 141 & PAHs & 40 & Lignin & 49 & $\begin{array}{l}\text { Manganese } \\
\text { peroxidase }\end{array}$ & 55 \\
\hline 11 & Fungi & 141 & Basidiomycete & 35 & Degradation & 42 & Lignocellulose & 41 \\
\hline 12 & Degradation & 112 & Fungi & 33 & Fungi & 41 & Degradation & 40 \\
\hline 13 & Pleurotus ostreatus & 103 & Textile dyes & 32 & Lignin peroxidase & 38 & Trametes versicolor & 40 \\
\hline 14 & PAHs & 101 & Ligninolytic enzymes & 31 & Pleurotus ostreatus & 38 & Pleurotus ostreatus & 39 \\
\hline 15 & Lignin peroxidase & 88 & Degradation & 30 & PAHs & 35 & Pretreatment & 32 \\
\hline 16 & Lignocellulose & 76 & Lignin peroxidase & 26 & Dye decolorization & 32 & Lignin degradation & 31 \\
\hline 17 & Lignin degradation & 72 & Pleurotus ostreatus & 26 & Dyes & 30 & Delignification & 30 \\
\hline 18 & Dyes decolorization & 70 & $\begin{array}{l}\text { Ceriporiopsis } \\
\text { subvermispora }\end{array}$ & 24 & Biosorption & 29 & $\begin{array}{l}\text { Lignocellulose } \\
\text { biomass }\end{array}$ & 26 \\
\hline 19 & Biosorption & 66 & Azo dyes & 23 & Basidiomycetes & 27 & PAHs & 26 \\
\hline 20 & Immobilization & 63 & Biopulping & 22 & Immobilization & 27 & Biosorption & 24 \\
\hline
\end{tabular}


keywords "lignocellulose"“pretreatment"“lignin"“lignin degradation"“delignification"and "lignocellulose biomass" is higher than other keywordsand it has been used frequently in recent years. In particular"pretreatment" and "ligocellulose biomass" ranked more than 150 before 2008and increased rapidly to 15th and 18th in 2015-2020respectively. Another notable change is the keyword "delignification," which ranked 78th in 2003-2008then increased to 27st in 20092004and 17th in 2015-2020. In addition"ligocellulose" also increased from 48th in 2003-2008 to 11th in 2015-2020. The microbial degradation of lignocellulosic biomass is considered to be an efficient and economical way for the utilization of biomass waste. Howeverthere is a major obstacle to energy production because lignocellulosic biomass contains lignin which is difficult to be transformed (Rouches et al. 2016). In this caseWRF is considered to be the most capable microorganisms for delignification pretreatment of waste biomass resources (Isroi et al. 2011). In contrastthe author keywords "textile dyes," "biopulping"and "Ceriporiopsis subvermispora" lost attention in the research periodbecause their ranking in the list of frequently used keywords dropped significantly. Among them"textile dyes" and "biopulping" ranked 13th and 20th in 2003-2008 respectivelyand then dropped sharply to less than 200th place in 2015-2020

The top 10 author keywords and their frequency from 2003 to 2020 are shown in Fig. S1, "lignnolytic enzymes" frequently appear in the top 10 author keywords list after 2010, while "Trametes versicolor" hardly appears after 2014. After 2011, the frequency of "decoloration" has also decreased year by year, and it did not even appear in the top10 list of 2018 and 2019. Similarly, "PAHs" disappeared in the top 10 list after 2011. In contrast, "pretreatment", "mycoremediation", "anaerobic digestion", "lignocellulose", and "immobilization" began to appear in the top10 author keyword list from 2017 to 2019.

In order to compare the research focus of different countries, Table S4 lists the top 20 author keywords in the five countries with the most contributions to this research. It was apparent that Phanerochaete chrysosporium was the most commonly used WRF strain in China, USA, India, and Japan, strain A, while Trametes versicolor was the most widely used strain in Spain. The "PAHs", "biosorption", and "corn stover" only appears in the top 20 keywords of China, while "pretreatment", "wood decay", "enzymatic hydrolysis", and "ethanol" only appears in the top 20 keywords of USA. In the study of India, the author keywords "delignification", "azo dyes", "wheat straw", "response surface methodology", and "optimization" have a higher ranking than other countries. During the retrieval period, "cytochrome P450", "Phanerochaete sordida", "hydroxylation", "Lentinula edodes", "estrogenic activity", and "dioxin" entered the top 20 keywords of Japan, indicating these were full of research interests. Moreover, Spain pays more attention to "versatile peroxidase", "Trametes hirsute", "bioethanol", "phytotoxicity", "pharmaceuticals", and "anthracene".

Visualization of co-occurrence keywords

This study carried out cluster analysis of author keywords that appeared more than 16 times to reflect the close relationship between keywords, and determine the mainstream research direction in this field. In general, keywords with strong correlation are close to each other. The co-occurrence frequency of keywords in the same cluster is high, which jointly represents a similar research field. According to the result of cluster analysis as shown in Fig. 6a, 130 author keywords were clustered into seven categories depicted in different colors, of which clusters 1,2, and 3 are the main clusters with more author keywords. Cluster 1, the largest cluster with 30 author keywords, was marked in red, focused on the pretreatment of biomass waste by WRF for biopulping, energy production or lignin modification, etc., mainly including "lignin", "lignin degradation", "delignification", "lignocellulose", "wheat straw", "biopulping", "biological pretreatment", "enzymatic hydrolysis", "Ceriporiopsis subvermispora", "lignocellulosic biomass", etc. Cluster 2 has 26 author keywords, with green items, focused on the application of WRF and its enzymes in decolorization of dye wastewater, with keywords of "laccase", "decolorization", "decolourization", "Trametes versicolor", "biosorption", "kinetics", "immobilization", "azo dyes", "dye", "textile dyes", etc. Cluster 3 has 25 author keywords, with blue items, focused on the ability of WRF to remove environmental pollutants, including the main keywords of "biodegradation", "bioremediation", "Phanerochaete chrysosporium", "degradation", "fungi", "Pleurotus pstreatus", "ligninolytic enzymes", "PAHs", "biotransformation", "mycoremediation", "pesticides", etc.

Furthermore, the density visualization map of author keywords and hotspots intensity with color spectrum was shown in Fig. 6b, where warm colors represents hot research fields and cool colors represents cool research fields. The author keywords with the dark red are "laccase", "white rot fungi", "Phanerochaete chrysosporium", "biodegradation", "Trametes versicolor", "bioremediation", "decolorization", "ligninolytic enzymes", and "manganese peroxidase", which indicated that these research contents represented by these keywords are important research hotspot from 2003 to 2020 all over the world.

Burst detection analysis

Burst keywords refer to words whose appearance frequency suddenly increased in some period. In general, the stronger the burst strength of keywords, the more likely the topic will become emerging research frontiers (Gao et al. 2019). In this study, CiteSpace V was used to identify the burst keywords, and the top 50 keywords with the strongest bursts is shown in Fig. 7, where the length of the entire line (green and red) in the last column represents the research period from 2003 to 2020, and the red line represents the burst period. On the whole, the 


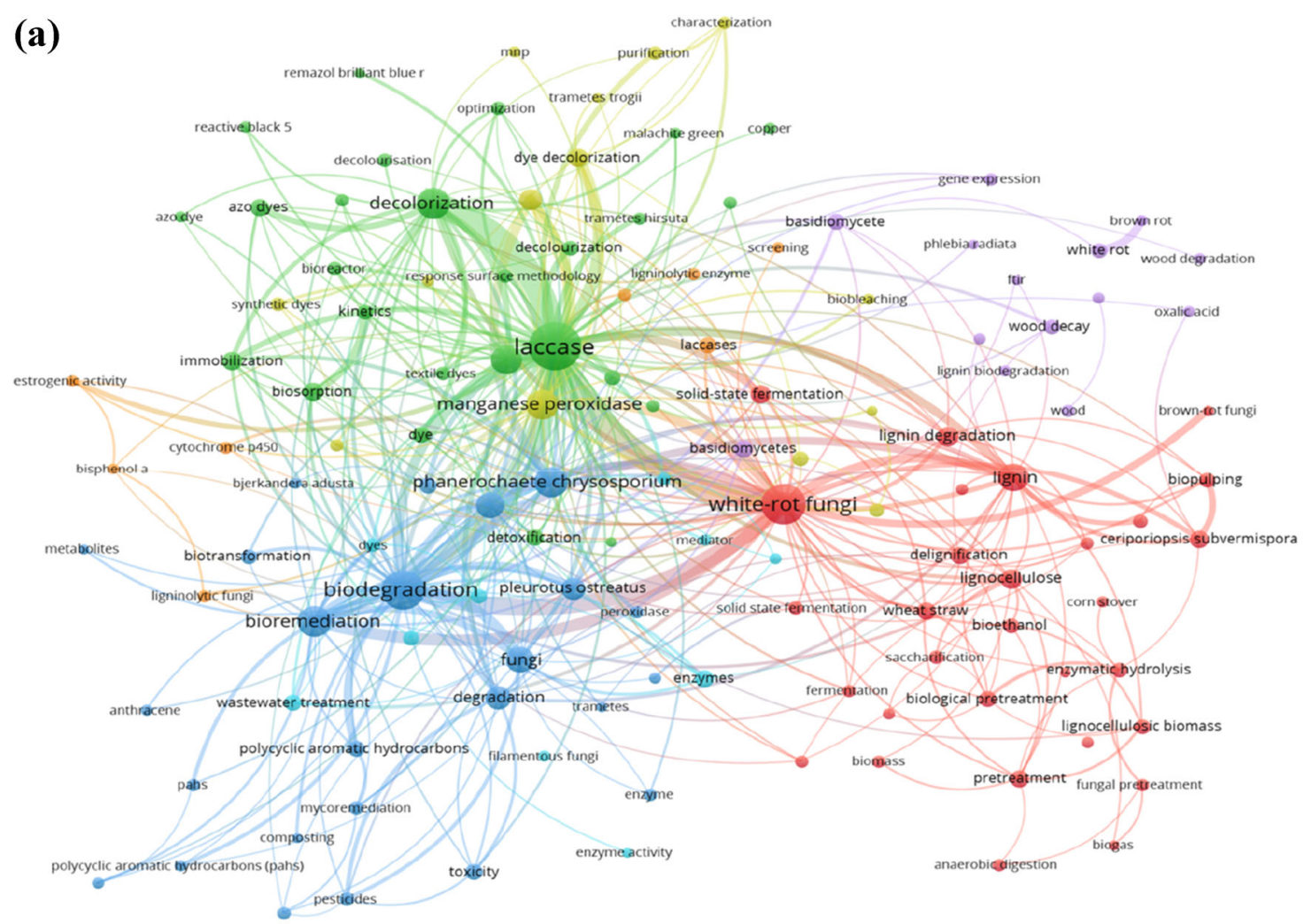

(b)

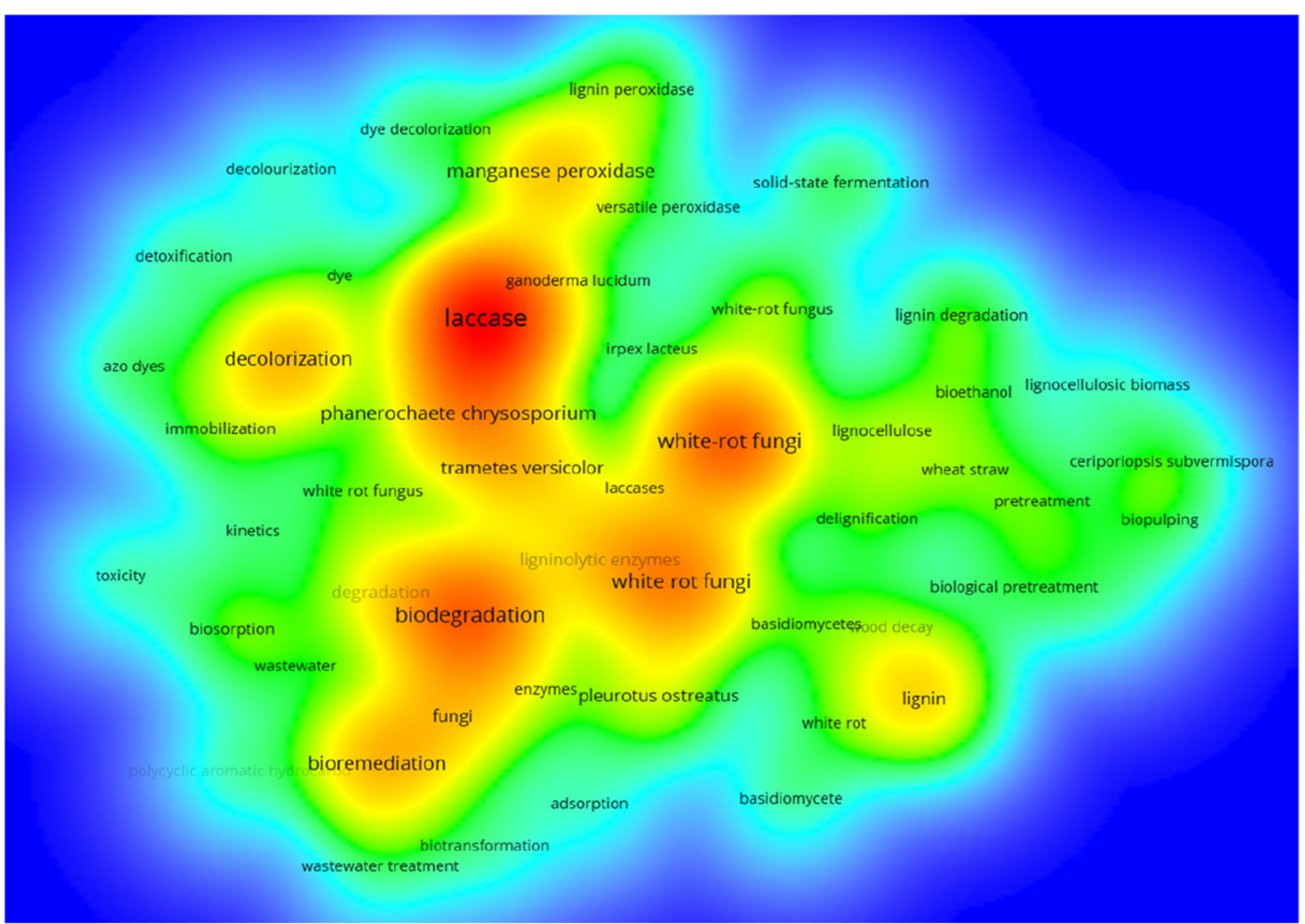

Fig. 6 The network visualization map (a) and density visualization map (b) of co-occurrence keywords in the researches on WRF biotechnology for environmental application 
Fig. 7 Top 50 keywords with the strongest citation bursts in the researches on WRF biotechnology for environmental application

\begin{tabular}{|c|c|c|}
\hline Keywords & Strength Begin & $2003-2020$ \\
\hline Bjerkandera adusta & 13.03792003 & 2007 \\
\hline phenanthrene & 4.06852003 & 2006 200 \\
\hline Pleurotus eryngii & 10.78472003 & 2006 تصعس \\
\hline lignin peroxidase & 9.20952003 & تصعصة 2006 \\
\hline white-rot fungi & 5.96082003 & 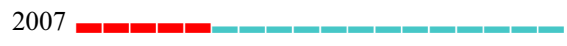 \\
\hline hydrogen peroxide & 7.73442003 & تصعصב 2006 \\
\hline bioreactor & 5.97322003 & عصعس 2006 \\
\hline lipid peroxidation & 6.15942003 & 2005 \\
\hline mineralization & 13.21732003 & تصعصصصصم 2010 \\
\hline Coriolus versicolor & 14.42162003 & . \\
\hline Phanerochaete chrysosporium & 10.39952003 & عصعصصع 2008 \\
\hline metabolism & 12.08892003 & عبسعصع 2010 \\
\hline decolourisation & 7.45342003 & 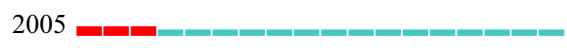 \\
\hline oxidation & 11.77862003 & عصصص 2006 \\
\hline culture & 19.05732003 & عصבصعصב 2009 \\
\hline manganeseperoxidase & 3.27882004 & 2006 - \\
\hline oxidase & 10.06972004 & 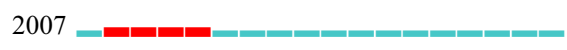 \\
\hline versicolor & 5.53522004 & 2006 - 200 \\
\hline anthracene & 4.98132004 & 2006 בصع \\
\hline kraft pulp & 9.06132004 & 2007 - \\
\hline effluent & 15.24222005 & 2010 \\
\hline enzyme production & 7.42642006 & 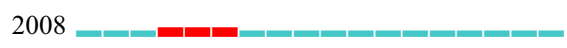 \\
\hline wastewater & 11.7572006 & 2010 \\
\hline transformation & 4.90812006 & 2010 \\
\hline phenol & 6.80942007 & 2009 \\
\hline reactive dye & 5.51632007 & $2011=$ \\
\hline acid & 8.14992008 & 2010 \\
\hline optimization & 11.32352008 & سمسعـ \\
\hline waste & 7.55752008 & عسمس -س \\
\hline laccase production & 9.73922008 & . \\
\hline decolourization & 12.4882009 & مسعس-س - \\
\hline Aspergillus niger & 7.49542009 & 2011 \\
\hline contaminated soil & 6.89662009 & 2011 \\
\hline identification & 4.87032013 & 2016 \\
\hline adsorption & 7.78452013 & 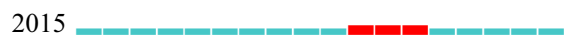 \\
\hline enzymatic hydrolysis & 22.10722013 & مسعسعسعس- \\
\hline cellulose & 7.45782013 & 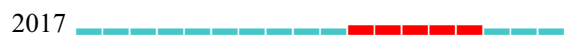 \\
\hline pretreatment & 21.6682013 & سعسعسعس \\
\hline detoxification & 6.80692014 & _-_ع_ع_ \\
\hline decay & 5.31922015 & _-_ع_س_ \\
\hline brown rot & 7.6782015 & سعسعسع- \\
\hline lignocellulose & 13.80122015 & 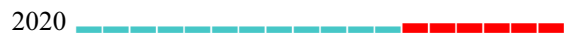 \\
\hline chemical composition & 20.98012015 & 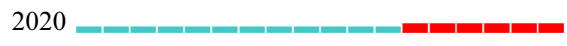 \\
\hline toxicity & 12.03422016 & 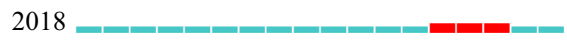 \\
\hline lignocellulosic biomass & 33.82572016 & 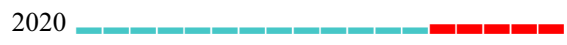 \\
\hline bisphenol A & 4.32212016 & 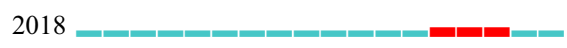 \\
\hline biological pretreatment & 12.87962016 & 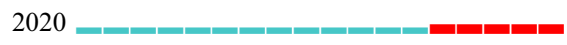 \\
\hline wood decay & 11.65662017 & 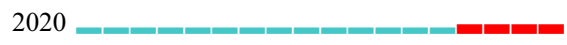 \\
\hline pesticide & 7.0312017 & 2020 - \\
\hline solid state fermentation & 4.60442017 & שח 2020 - \\
\hline
\end{tabular}

high frequency keywords with low burst strength were classical terms that have been stably cited during the whole research period, while the low frequency keywords with high burst strength have attracted more attention in a certain research period, which may represent an emerging research direction.
Based on the results of burst keywords detection, three development stages in application of WRF biotechnology in environmental field in the past 20 years was identified. In the first stage before 2004, "Bjerkandera, adusta", "Pleurotus eryngii", "mineralization", "Coriolus versicolor", 
"Phanerochaete, chrysosporium", "metabolism", "oxidation", "oxidase", and "culture" had higher burst strength (> 10.0), while "mineralization", "metabolism", and "culture" showed longer burst period, indicating that they were the frontier technologies in this period. The burst keywords in the second stage from 2005 to 2012 include "effluent", "wastewater", "optimization", "decolourization", "reactive dye", "waste", "contaminated soil", and "phenol". At this stage, researchers have realized the advantages of the application of fungal biotechnology in the environmental pollution control, and the value of WRF in bioremediation has been continuously discovered. Many studies have successfully applied WRF to the remediation of contaminated soil and water. The third stage was from 2013 to 2020, the major keywords include "lignocellulosic biomass" (33.83), "enzymatic hydrolysis" (22.11), "pretreatment" (21.67), "chemical composition" (20.98), "lignocelluloses" (13.80), "biological pretreatment" (12.88), "toxicity" (12.03), and "wood decay" (11.66), according to their burst strength. Moreover, the above keywords and "pesticide", "brown rot", "solid state fermentation" have a long burst period, which has extended to 2020 . These emerging burst keywords can provide inspiration sources for researchers to propose new research topics and perspectives for future research (Qi et al. 2019).

To determine which authors are the active in a specific period of time, burst detection of authors was performed. Figure S2 shows the burst authors in the research field of WRF biotechnology for environmental application from 2012 to 2020. Among the 28 authors, 6 are from China, 4 from Spain and the Netherlands, 2 from Italy, Malaysia and USA, and 8 from other different countries. The burst period of 9 authors extends to 2020, in which the burst period of Asif MB and Ma FY started in 2017, and that of Ma Q, Helm CV, van Erven G, Yang ST, Nayan N, Kable MA, and Peng M started in 2018. Tracking the research of these burst authors is instrumental for us to grasp the latest development trend of specific research field. Ma FY mainly carried out the research on the application of WRF such as Pleurotus ostreatus and Irpex lacteus and their lignocellulolytic enzymes in dye decolorization and delignification (Ma et al. 2017). In the recent report of Asif MB, some high efficiency enzymatic membrane bioreactors were constructed to remove trace organic contaminants (Asif et al. 2018). Ma Q and Yang ST are from the same team of Southwest Minzu University in China, and they mainly studied the toxicity of carbon-based nanomaterials such as nanodiamonds, carbon nanotubes and graphene to WRF, and fungal transformation of these nanomaterials by WRF (Ma et al. 2019; Ming et al. 2018). The research of Helm CV mainly focuses on the decolorization of textile industry wastewater by Oudemansiella canarii and Fanoderma lucidum on solid state fermentation with sugarcane bagasse-wheat bran mixture or peach palm residue as substrates (Chicatto et al. 2018). Nayan N, van Erven G and Kabel MA are all from
Wageningen University and Research in the Netherlands, and their main work is to screen WRF capable of pretreatment of wheat straw to improve their nutritional value or ruminal digestibility for ruminant feeding (Nayan et al. 2019).

Research hotspots and future trends

As a result of human activities, the accumulation of lignocellulosic wastes gradually has evolved into an environmental problem that cannot be ignored. The pretreatment of lignocellulose is a critical step in production of value-added products such as biofuel and enzymes from woody materials (Sharma et al. 2019). Among various pretreatments of lignocellulose, WRF are gaining popularity due to its financial and environmental benefits (Ding et al. 2019). Several studies have found that the combination of WRF pretreatment with other physicochemical methods cannot only reduce the time necessary for the whole process, but also introduce cost-effectiveness (Shirkavand et al. 2016; Xie et al. 2017). Anaerobic digestion of lignocellulosic biomass has been considered as an efficient way to produce energy (Kainthola et al. 2021). However, application of WRF in the pretreatment of substrates for anaerobic digestion started late, and further exploration is necessary.

In recent studies, whole-cell WRF or its extracellular extracts have been successfully applied to remove trace organic contaminants (TrOC) in aqueous phase (Asif et al. 2017a). Whole-cell WRF or their extracellular lignin-modifying enzymes (LMEs) have also been reported to degrade pesticide, graphene-related materials, pharmaceuticals, and personal care products that are persistent to the environment (Asif et al. 2017b; Xiao and Kondo 2020b; Carniel et al. 2021; Jureczko and Przystas 2021). Meanwhile, the use of cross-linked enzyme aggregates (CLEAs) such as porous-, combi-, or magnetic CLEAs to immobilize LMEs is a promising technology to overcome the stability and non-reusability of free LMEs from WRF in wastewater treatment (Vrsanska et al. 2018; Voberkova et al. 2018). Another recent focus is use of WRF as low cost and efficient adsorbent for the removal of heavy metal from wastewater (Noormohamadi et al. 2019; Kocaoba et al. 2021). On the other hand, WRF or immobilized WRF also showed excellent application potential in remediation of contaminated soils (Kaewlaoyoong et al. 2020; Li et al. 2020; Wang et al. 2020; Ma et al. 2021). In addition, recent studies have proved that white rot fungi may be one of the effective bio-treatment ways to inhibit algal blooms (Zeng et al. 2020).

Furthermore, the combination of WRF and nanomaterials for pollutant removal is regarded as a highly competitive technology, which is also called nanobiotechnology. Some researchers have pointed out that the stability and treatment performance of WRF can be greatly improved by adding nanoparticles as carriers or synergists to the wastewater treatment systems (He et al. 2017; Huang et al. 2018). At the same time, it is necessary to investigate the environmental 
bio-effects of nanomaterials on WRF to ensure the safe applications (Ma et al. 2020). Recent research have confirmed that WRF can produce $\mathrm{HO}$ - with strong oxidation through a Fenton-like process, and then improve the degradation effect of pollutants in wastewater (Vasiliadou et al. 2019). Therefore, the combining WRF biotechnology with advanced oxidation processes and maximizing their respective advantages in wastewater treatment is also one the research frontiers in the future (Hou et al. 2020; Xiao et al. 2020).

At present, studies on degradation performance of WRF are mainly focused on sterile batch tests, while few studies have been conducted on the bioreactor scale under non-sterile conditions and in continuous mode. Since the performance of WRF will be seriously affected by bacterial contamination, the large-scale application of WRF in bioremediation remains a technical challenge, and more exploration is needed to improve this limitation (Asif et al. 2017b; Svobodova and Novotny 2018). In addition, although the practical use of WRF biotechnology in environmental remediation shows its unique charm, it is necessary to make breakthroughs in process optimization and cost reduction before this goal can be achieved (Rodríguez-Couto 2017).

\section{Conclusions}

Based on 3967 documents retrieved from the WoSCC database, a bibliometric analysis on the evolution and development of WRF biotechnology for environmental applications was carried out in order to fully understand the publications, the most productive countries, institutions, authors, journals, and research categories, as well as research hotspots and future research directions. These results are helpful for researchers to analyze the existing publications, thereby helping them improve their research direction and keep up with the research frontier. This is an important contribution because it is the first time conduct a relatively objective and comprehensive bibliometric analysis on the research field of WRF biotechnology for environmental application in a global scale. However, it must be pointed out that there are still some unavoidable limitations in this study, just like any studies. Due to the incomplete search items, some relevant articles may have been missed, while some irrelevant articles may be collected. Also, the citation analysis does not exclude self-citation, which may lead to the fact that the results of citation analysis cannot fully and accurately reflect the academic influence represented. Furthermore, some high quality non-English publications were not included in this study, which will lead to incomplete analysis. In future research, these deficiencies will be corrected in order to draw obtain more detailed and accurate research conclusions.

Author contribution Pengfei Xiao: data collection and analysis, funding acquisition, investigation, methodology, visualization, writing - original draft; Dedong Wu: writing - review and editing; Jianqiao Wang: validation. All authors read and approved the final manuscript.

Funding This work was supported by the Natural Science Foundation of Heilongjiang Provincial of China (LH2019D002).

Data availability The datasets used and/or analyzed during the current study are available from the corresponding author on reasonable request.

\section{Declarations}

Ethics approval and consent to participate Not applicable.

Consent for publication Not applicable.

Competing interests The authors declare no competing interests.

\section{References}

Almetwally AA, Bin-Jumah M, Allam AA (2020) Ambient air pollution and its influence on human health and welfare: an overview. Environ Sci Pollut Res 27:24815-24830

AlRyalat SAS, Malkawi LW, Momani SM (2019) Comparing bibliometric analysis using PubMed, Scopus, and Web of Science Databases. Jove J Vis Exp 152:e58494

Asif MB, Hai FI, Hou J, Price WE, Nghiem LD (2017a) Impact of wastewater derived dissolved interfering compounds on growth, enzymatic activity and trace organic contaminant removal of white rot fungi - a critical review. J Environ Manag 201:89-109

Asif MB, Hai FI, Singh L, Price WE, Nghiem LD (2017b) Degradation of pharmaceuticals and personal care products by white-rot fungi- $\mathrm{a}$ critical review. Curr Pollut Rep 3:88-103

Asif MB, Hai FI, Dhar BR, Ngo HH, Guo W, Jegatheesan V, Price WE, Nghiem LD, Yamamoto K (2018) Impact of simultaneous retention of micropollutants and laccase on micropollutant degradation in enzymatic membrane bioreactor. Bioresour Technol 267:473-480

Cabana H, Jones JP, Agathos SN (2007) Elimination of endocrine disrupting chemicals using white rot fungi and their lignin modifying enzymes: a review. Eng Life Sci 7:429-456

Carniel FC, Fortuna L, Zanelli D, Garrido M, Vazquez E, Gonzalez VJ, Prato M, Tretiach M (2021) Graphene environmental biodegradation: wood degrading and saprotrophic fungi oxidize few-layer grapheme. J Hazard Mater 414:125553

Chen H, Jiang W, Yang Y, Yang Y, Man X (2015) Global trends of municipal solid waste research from 1997 to 2014 using bibliometric analysis. J Air Waste Manage Assoc 65:1161-1170

Chen W, Geng Y, Zhong S, Zhuang M, Pan H (2020) A bibliometric analysis of ecosystem services evaluation from 1997 to 2016. Environ Sci Pollut Res 27:23503-23513

Chicatto JA, Rainert KT, Goncalves MJ, Helm CV, Altmajer-Vaz D, Tavares LBB (2018) Decolorization of textile industry wastewater 
in solid state fermentation with peach-palm (Bactris gasipaes) residue. Braz J Biol 78:718-727

Crini G (2006) Non-conventional low-cost adsorbents for dye removal: a review. Bioresour Technol 97:1061-1085

Ding C, Wang X, Li M (2019) Evaluation of six white-rot fungal pretreatments on corn stover for the production of cellulolytic and ligninolytic enzymes, reducing sugars, and ethanol. Appl Microbiol Biotechnol 103:5641-5652

Dogan D, Boran F, Kahraman S (2018) Dye removal by dead biomass of newly isolated Pleurotus ostreatus strain. Indian J Biotechnol 17: 290-301

Forgace E, Cserhati T, Oros G (2004) Removal of synthetic dyes from wastewaters: a review. Environ Int 30:953-971

Gao Y, Ge L, Shi S, Sun Y, Liu M, Wang B, Shang Y, Wu J, Tian J (2019) Global trends and future prospects of e-waste research: a bibliometric analysis. Environ Sci Pollut Res 26:17809-17820

Grelska A, Noszczynska M (2020) White rot fungi can be a promising tool for removal of bisphenol A, bisphenol S, and nonylphenol from wastewater. Environ Sci Pollut Res 27:39958-39976

Harry-Asobara JL, Kamei I (2019) Characteristics of white-rot fungus Phlebia brevispora TMIC33929 and its growth-promoting bacterium Enterobacter sp. TN3W-14 in the decolorization of dyecontaminated water. Appl Biochem Biotechnol 189:1183-1194

He K, Chen G, Zeng G, Huang Z, Guo Z, Huang T, Peng M, Shi J, Hu L (2017) Applications of white rot fungi in bioremediation with nanoparticles and biosynthesis of metallic nanoparticles. Appl Microbiol Biotechnol 101:4853-4862

He M, Zhang Y, Gong L, Zhou Y, Song X, Zhu W, Zhagn M, Zhang Z (2019) Bibliometrical analysis of hydrogen storage. Int J Hydrog Energy 44:28206-28226

Hou L, Ji D, Dong W, Yuan L, Zhang F, Li Y, Zang L (2020) The synergistic action of electro-Fenton and white-rot fungi in the degradation of lignin. Front Bioeng Biotechnol 8:99

Huang D, Guo X, Peng Z, Zeng G, Xu P, Gong X, Deng R, Xue W, Wang R, Yi H, Liu C (2018) White rot fungi and advanced combined biotechnology with nanomaterials: promising tools for endocrine-disrupting compounds biotransformation. Crit Rev Biotechnol 38:671-689

Isroi MR, Syamsiah S, Niklasson C, Cahyanto MN, Lundquist K, Taherzadeh MJ (2011) Biological pretreatment of lignocelluloses with white-rot fungi and its applications: a review. Bioresources 6: 5224-5259

Jureczko M, Przystas W (2021) Removal of two cytostatic drugs: bleomycin and vincristine by white-rot fungi - a sorption study. J Environ Health Sci 19:651-662

Kaewlaoyoong A, Cheng C, Liu C, Chen J, Huang W, Sriprom P (2020) White rot fungus Pleurotus pulmonarius enhanced bioremediation of highly PCDD/F-contaminated field soil via solid state fermentation. Sci Total Environ 738:139670

Kainthola J, Podder A, Fechner M, Goel R (2021) An overview of fungal pretreatment processes for anaerobic digestion: applications, bottlenecks and future needs. Bioresour Technol 321:124397

Kiran S, Huma T, Jalal F (2019) Lignin degrading system of Phanerochaete chrysosporium and its exploitation for degradation of synthetic dyes wastewater. Pol J Environ Stud 28:1749-1757

Kocaoba S, Parlak MD, Arisoy M (2021) The use of Phanerochaete chrysosporium for modification of bentonite for preconcentration and determination of heavy metals. J Anal Sci Technol 12:24

Lebkowska M, Zaleska-Radziwill M (2014) Application of white-rot fungi for biodegradation of refractory organic compounds-a review. Desalin Water Treat 52:19-21

Legerska B, Chmelova D, Ondrejovic M (2018) Decolourization and detoxification of monoazo dyes by laccase from the white-rot fungus Trametes versicolor. J Biotechnol 285:84-90

Li C, Wu K, Wu J (2017) A bibliometric analysis of research on haze during 2000-2016. Environ Sci Pollut Res 24:24733-24742
Li C, Ji X, Luo X (2019) Phytoremediation of heavy metal pollution: a bibliometric and scientometric analysis from 1989 to 2018. Int J Environ Res Public Health 16:4755

Li Z, Wang X, Ni Z, Bao J, Zhang H (2020) In-situ remediation of carbofuran-contaminated soil by immobilized white-rot fungi. Pol J Environ Stud 29:1237-1243

Ma F, Huang X, Ke M, Shi Q, Shi C, Zhang J, Zhang X, Yu H (2017) Role of Selective fungal delignification in overcoming the saccharification recalcitrance of bamboo culms. ACS Sustain Chem Eng 5: 8884-8894

Ma Q, Yilihamu A, Ming Z, Yang S, Shi M, Ouyang B, Zhang Q, Guan $X$, Yang S (2019) Biotransformation of pristine and oxidized carbon nanotubes by the white rot fungus Phanerochaete chrysosporium. Nanomaterials 9:1340

Ma Q, Zhang Q, Yang S, Yilihamu A, Shi M, Ouyang B, Guan X, Yang S (2020) Toxicity of nanodiamonds to white rot fungi Phanerochaete chrysosporium through oxidative stress. Colloids Surf B 187: 110658

Ma X, Li X, Liu J, Cheng Y, Zou J, Zhai F, Sun Z, Han L (2021) Soil microbial community succession and interactions during combined plant/white-rot fungus remediation of polycyclic aromatic hydrocarbons. Sci Total Environ 752:152224

Malachova K, Rybkova Z, Sezimova H (2013) Biodegradation and detoxification potential of rotating biological contactor (RBC) with Irpex lacteus for remediation of dye-containing wastewater. Water Res 47:7143-7148

Ming Z, Feng S, Yilihamu A, Yang S, Ma Q, Yang H, Bai Y, Yang S (2018) Toxicity of carbon nanotubes to white rot fungus Phanerochaete chrysosporium. Ecotoxicol Environ Saf 162:225234

Mir-Tutusaus JA, Baccar R, Caminal G, Sarra M (2018) Can white-rot fungi be a real wastewater treatment alternative for organic micropollutants removal? A review. Water Res 138:137-151

Nayan N, van Erven G, Kabel MA, Sonnenberg ASM, Hendriks WH, Cone JW (2019) Improving ruminal digestibility of various wheat straw types by white-rot fungi. J Sci Food Agric 99:957-965

Noormohamadi HR, Fathi MR, Ghaedi M, Ghezelbash GR (2019) Potentiality of white-rot fungi in biosorption of nickel and cadmium: modeling optimization and kinetics study. Chemosphere 216:124-130

Qi Y, Chen X, Hu Z, Song C, Cui Y (2019) Bibliometric analysis of algalbacterial symbiosis in wastewater treatment. Int J Environ Res Public Health 16:1077

Rodríguez-Couto S (2017) Industrial and environmental applications of white-rot fungi. Mycosphere 8:456-466

Rouches E, Herpoël-Gimbert I, Steyer JP, Carrere H (2016) Improvement of anaerobic degradation by white-rot fungi pretreatment of lignocellulosic biomass: a review. Renew Sust Energ Rev 59:179-198

Sharma HK, Xu C, Qin W (2019) Biological pretreatment of lignocellulosic biomass for biofuels and bioproducts: an overview. Waste Biomass Valori 10:235-251

Shirkavand E, Baroutian S, Gapes DJ, Young BR (2016) Combination of fungal and physicochemical processes for lignocellulosic biomass pretreatment - a review. Renew Sust Energ Rev 54:217-234

Singh P, Borthakur A (2018) A review on biodegradation and photocatalytic degradation of organicpollutants: a bibliometric and comparative analysis. J Clean Prod 196:1669-1680

Singh M, Srivastava PK, Verma PC (2015) Soil fungi for mycoremediation of arsenic pollution in agriculture soils. J Appl Microbiol 119:1278-1290

Svobodova K, Novotny C (2018) Bioreactors based on immobilized fungi: bioremediation under non-sterile conditions. Appl Microbiol Biotechnol 102:39-46

Usman M, Ho YS (2020) A bibliometric study of the Fenton oxidation for soil and water remediation. J Environ Manag 270:110886

van Eck NJ, Waltman L (2010) Software survey: VOSviewer, a computer program for bibliometric mapping. Scientometrics 84:523-538 
Vanzetto GV, Thomé A (2019) Bibliometric study of the toxicology of nanoescale zero valent iron used in soil remediation. Environ Pollut 252:74-83

Vasiliadou IA, Molina R, Pariente MI, Christoforides KC, Martinez F, Melero JA (2019) Understanding the role of mediators in the efficiency of advanced oxidation processes using white-rot fungi. Chem Eng J 359:1427-1435

Voberkova S, Solcany V, Vrsanska M, Adam V (2018) Immobilization of ligninolytic enzymes from white-rot fungi in cross-linked aggregates. Chemosphere 202:694-707

Vrsanska M, Voberkova S, Jiménez AMJ, Strmiska V, Adam V (2018) Preparation and optimisation of cross-linked enzyme aggregates using native isolate white rot fungi Trametes versicolor and Fomes fomentarius for the decolourisation of synthetic dyes. Int J Environ Res Public Health 15:23

Wang X, Song L, Li Z, Ni Z, Bao J, Zhang H (2020) The remediation of chlorpyrifos-contaminated soil by immobilized white-rot fungi. J Serb Chem Soc 85:857-868

Xiao P, Kondo R (2019) Biodegradation and bioconversion of endrin by white rot fungi, Phlebia acanthocystis and Phlebia brevispora. Mycoscience 60:255-261

Xiao P, Kondo R (2020a) Potency of Phlebia species of white rot fungi for the aerobic degradation, transformation and mineralization of lindane. J Microbiol 58:395-404

Xiao P, Kondo R (2020b) Biodegradation and biotransformation of pentachlorophenol by wood-decaying white rot fungus Phlebia acanthocystis TMIC34875. J Wood Sci 66:2
Xiao P, An L, Wu D (2020) The use of carbon materials in persulfatebased advanced oxidation precesses: a review. New Carbon Mater 35:667-683

Xie C, Gong W, Yang Q, Zhu Z, Yan L, Hu Z, Peng Y (2017) White-rot fungi pretreatment combined with alkaline/oxidative pretreatment to improve enzymatic saccharification of industrial hemp. Bioresour Technol 243:188-195

Yang S, Sui J, Liu T, Wu W, Xu S, Yin L, Pu Y, Zhang X, Zhang Y, Shen B, Liang G (2018) Trends on $\mathrm{PM}_{2.5}$ research, 1997-2016: a bibliometric study. Environ Sci Pollut Res 25:12284-12298

Yehia RS, Rodriguez-Couto S (2017) Discoloration of the azo dye Congo Red by manganese-dependent peroxidase from Pleurotus sajor caju. Appl Biochem Microbiol 53:222-229

Zeng G, Zhang M, Wang Y, Wang P, Wu P, Li X, Wen X (2020) Growth inhibition of eutrophication water by white-rot fungus. Fresenius Environ Bull 29:743-748

Zhang S, Mao G, Crittenden J, Liu X, Du H (2017) Groundwater remediation from the past to the future: a bibliometric analysis. Water Res 119:114-125

Zhuo R, Fan F (2021) A comprehensive insight into the application of white rot fungi and their lignocellulolytic enzymes in the removal of organic pollutant. Sci Total Environ 778:146132

Publisher's note Springer Nature remains neutral with regard to jurisdictional claims in published maps and institutional affiliations. 